\title{
Coming of Age, but Slowly: aspects of Canadian religious historiography since Confederation
}

John S. Moir

Volume 50, numéro 1, 1983

Bilan de l'histoire religieuse au Canada

Canadian Catholic History: A survey

URI : https://id.erudit.org/iderudit/1007037ar

DOI : https://doi.org/10.7202/1007037ar

Aller au sommaire du numéro

Éditeur(s)

Les Éditions Historia Ecclesiæ Catholicæ Canadensis Inc.

ISSN

0318-6172 (imprimé)

1927-7067 (numérique)

Découvrir la revue

Citer cet article

Moir, J. S. (1983). Coming of Age, but Slowly: aspects of Canadian religious historiography since Confederation. Sessions d'étude - Société canadienne d'histoire de l'Église catholique, 50(1), 89-98. https://doi.org/10.7202/1007037ar

Tous droits réservés ㄷ Les Éditions Historia Ecclesiæ Catholicæ Canadensis Inc., 1983
Ce document est protégé par la loi sur le droit d'auteur. L'utilisation des services d'Érudit (y compris la reproduction) est assujettie à sa politique d'utilisation que vous pouvez consulter en ligne.

https://apropos.erudit.org/fr/usagers/politique-dutilisation/ 


\title{
Coming of Age, but Slowly : aspects of Canadian religious historiography since Confederation*
}

\author{
by John S. MoIR \\ University of Toronto
}

"The work that lies before us is vast... There are no guides to sources, very few of the bibliographical, biographical and other helps to historians are available, indeed not a large amount of scholarly work of any kind has yet been done." "These words of Doctor Kenney in his first report to this Association as its secretary in 1933-4, provide one yardstick by which to judge the progress achieved in the past halfcentury. During those years, however, so many new forces have come into play that other measurements have become necessary. We can only guess at Dr. Kenney's reactions to the growth and change that have occurred if he were here today, but perhaps he might agree that the study of Canadian religious history, and especially Canadian Catholic history, is coming of age, however slowly.

In many ways the developments in Canadian religious history have parallelled those in Canadian secular history. Almost until World War I the writing of Canadian secular history was largely unscholarly, popular, even propagandistic, and very general in its content. Biographies were little more than political hagiographies, and of three multi-volume historical series produced in the decade before the War - Canada and its Provinces, the Chronicles of Canada, and the Makers of Canada -

* It is a regrettable commentary on Canada and upon us as historians that there is probably no one person capable of speaking authoritatively on the subject of state of religious history from sea to sea in this land. Two virtual solitudes seem to exist here too,, as though we had taken too much to heart to biblical injunction to let not one hand know what the other hand is doing. My remarks today are confined almost entirely to the anglophone historical scene because of ignorance of detail about the progress of my fellow but francophone historians.

${ }^{1}$ CCHA, Study Sessions 1933-34, p. 7. 
the collective biographies of the Makers of Canada were the least satisfactory and the shortest lived. It was World War I that created the first Canadian historiographical revolution. As dominion status and the structure of the British Commonwealth evolved from the crucible of conflict, Canadian secular historians became preoccupied for a full generation with attempts to discover the origins of Canadian nationality and the Commonwealth in Lord Durham's Report and in the practice of responsible government. The late Chester Martin's detailed Empire and Commonwealth (1929) is perhaps the most obvious example of this genre of historical writing from the era of Mackenzie King.

It took another World War to broaden Canadian historical perspectives, but that broadening process has also given us two generations of historical reductionism and balkanization. After the lead of Harold Innis in economic history came a proliferation of such special approaches to the Canadian experience. We developed historical lobbies to investigate urban history, social history, family history, labour history, military history, regional history, technological and scientific history, intellectual history and, perhaps in honesty we should add, religious history. At this moment we seem to have lost sight of the historical woods as we slashed away individually at our own particular historical tree. The end time of historical rassemblement, of synthesis in Canadian history, must be approaching - at least it should be approaching soon - a time when we can assess our achievements in specialized study and reconstruct a more meaningful (because more complete) picture of Canada's past.

But where has Canadian religious history stood in relation to these other historical interests? Research in Canadian religious history during the past century has shown parallel but slower development than Canadian secular history. Our national religious experience has been subject to most of the same forces as our secular experience - nationalism and particularly secularism - yet because religion is a universal or international experience the writing of Canadian religious history has been subject to external forces largely unknown in secular history, and not confined or confinable to national dimensions. Modernism, fundamentalism, ecumenism, liberalism, electronic evangelism, are the most obvious of those forces or developments that inevitably create elements in religious history that do not parallel our secular experience.

Over the years Canadian religious history has been written in several forms - biographies of the faithful (almost always hagiographic), congregational histories, regional or national denominational histories, 
and finally specialized studies of issues or movements such as churchstate relations or the social gospel. Biographies, congregational and regional denominational histories are by far the most numerous, the earliest and the least scholarly types. The specialized studies have come more recently, since 1945, and usually from the pens of professionals and academics which guarantees the books a certain immortality but not certain popularity! For Canada the new wave of secular biography, embodying the "warts and all" philosophy of history seems to date from Chester New's Lord Durham (1929) and for its religious counterpart from C.B. Sissons' Egerton Ryerson (1937, 1947). Religious biography, however seems almost inevitably to be constrained by the maxim nil nisi bonum, and no denomination really wants to hear too much about the humanness of its particular saints.

Canadian religious history in other forms than biography also seems to suffer from the same distortion. In past denominationalism projected into history gave the reader so often the impression that the only Christians, perhaps the only humans, to inhabit Canada were members of "Denomination X." The problem with denominational-hagiographic history is that at best it tends to become special pleading that glorifies self by ignoring others, and at its worst - when under stress - reacts with doctrinaire condemnation of others as "lesser breeds without the law." Neither situation is inevitable but too often it has been the practical result. On the other hand the more specialized and interpretive works in Canadian religious history too frequently fail to provide a comprehensive picture of the role of religion in the total social, intellectual and cultural life of Canada. We desperately need solid general histories of the denominations but even more we need an equivalent to Sydney Alhstrom's religious history of the American people to serve as the inspiration, yardstick and foundation for such histories.

Canadian religious history needs new philosophical approaches if we are to progress much beyond the incomplete and unsatisfactory stage the craft now enjoys. Canadian secular history has usually been written as a dichotomy of conflict - every issue has been examined and reported in terms of some language-based competition between French and English. Our recent admission that sectionalism is a major cause of internal tension has not disabused all historians of their black $v s$ white interpretation of past events. For Canadian religious history there was a similar dichotomous typology by which all Canadian 
religious history could be written in terms of Catholic $v s$ Protestant. ${ }^{2}$ Just as multiculturalism has replaced biculturalism, so in our writing of religious history that bi-religious view of our past is in process of giving way to a degree at least of recognition of religious pluralism in Canada.

Past attempts of Canadian historians (all of them Protestant) to provide some overview of our religious experience have been few in number and generally unsuccessful. E.H. Oliver's Winning of the Frontier (1933) was the first such attempt and Oliver tried only halfheartedly to impose F.J. Turner's dubious frontier thesis on top of the facts of Canadian religious history. Almost a quarter-century later H.H. Walsh produced The Christian Church in Canada (1956). Walsh, who be it noted confined his account to Christian history of Canada, fell between two stools. On one side was the criticism of such as A.R.M. Lower that the work told scholars nothing they did not already know, and on the other side the indisputable fact no author could singlehandedly fill the great lack of solid research into Canadian religious life.

One attempted solution to this dilemma was a compromise project for a multi-author survey. Walsh and Lorne Pierce, the editor-in-chief of Ryerson Press from 1920 to 1960, planned a three-volume study of Canadian church history - again be it noted not a study of Canadian

\footnotetext{
${ }^{2}$ Earlier Canadian church historians worked exclusively within a philosophical framework built on accepted Christian doctrine. Their successors may have attempted to modify that philosophy by introducing such overriding concepts as frontierism and dualism, but despite the obvious inadequacies of such secular inspired approaches more recent Canadian religious historians have, like their colleagues in Canadian secular historical studies, tended to avoid philosophizing about their discipline. More in the tradition of English historiography, they have talked about the "nuts and bolts" of their calling rather than its philosophical assumptions. N.K. Clifford and Roger O'Toole, both sociologists by training and the latter by employment, have offered analyses of trends in Canadian religious historiography combined with prophetic suggestions. See N.K. Clifford, "History of Religion in Canada", The Ecumenist, 18, 5 (1980), pp. 65-69, and Roger O'Toole, "Some Good Purpose: Notes on the Sociology of Religion in Canada", Annual Review of the Social Sciences of Religion, 6 (1982), pp. 177-217. See also F.A. Peake, "Reflections on Canadian Church History", Journal of the Canadian Church Historical Society, 22 (April, 1980), pp. 46-50, John W. Grant, "Asking Questions of the Canadian Past", Canadian Journal of Theology, 1, 2 (1955), pp. 98104, N.K. Clifford, "Religion and the Development of Canadian Society: an historiographic analysis", Church History, 38 (1969), pp. 506-523, and H.H. Walsh, "The Challenge of Canadian Church History to its Historians", Canadian Journal of Theology, 5, 3 (1959), pp. 162-169.
} 
religious history - as a tribute to the centenary of Canadian confederation, and after various tribulations the trilogy by Walsh, Moir and Grant appeared in 1972. This project too had its inherent problems. Economics dictated that the volumes be less than 200 pages each, thus severely restricting the approach of the authors. Perhaps even more crucial, the historiographic approach of the first two volumes was based more on institutional history than people-history. The result was a history that was already historiographically obsolescent thanks to two major intellectual developments. The first was the ecumenical winds of change unleashed at Vatican II. The second was the broadening approach to religious studies, evidenced by the new sociological interest in religion and by the new university departments of religion that absorbec' so much from the domain of theological seminaries.

The work of Lorne Pierce in promoting Canadian literature and bilingualism from his powerful position in the editorial chair has not received the acclaim it deserves, but it is more important here to note that this bishop of Canadian letters was responsible for the publication of a shelf of books on Canadian religious history at a time when few publishers would consider any manuscript in that field. Although Palm Publishers did produce some monographs on Canadian Catholic history, the quantity of religious history flowing from Ryerson Press during four decades of Pierce's oversight was much larger than that of any other Canadian publisher and perhaps equalled the production of all other presses combined in this particular field. The contribution of a second person to the postwar awakening interest in Canadian religious history has, however, passed entirely unnoticed. That person was Donald Grant Creighton who, beginning about 1950, encouraged such research by a small coteri of graduate students, and at least two of their doctoral theses were subsequently published as monographs. As Pierce used his position to disseminate and popularize Canadian religious history in print, Creighton's involvement at the university level did much to legitimate such studies in the eyes of secular historians.

By the mid-1960s the Canadian religious history scene was again in a revolutionary phase, and the changes that followed were more striking than those that had separated the periods before and immediately after World War I. Laymen trained in history were entering the field of religious history and gaining acceptance from the seminary professors who previously dominated the teaching and writing of church history. Both undergraduate and graduate courses on Canadian religious history were now offered at some institutions. The Canadian Journal of Theology, begun in 1955, had become the major vehicle for publication 
of research in the field, and a substantial number of monograph studies, often based on graduate theses, were appearing. By 1960 the Canadian Society of Church History (its name admittedly reflecting an institutional approach) was established with hopes of becoming a scholarly, bilingual, non-denominational organization. Those hopes have not been realized but the past score of years has seen, interestingly, the founding of several more denominational historical societies (in addition to the older Catholic and Anglican ones) - and included among the new groups is a society for Canadian Jewish studies.

Canadian religious history seemed in this second revolution to becoming of age. An awakened public interest and an awakened scholarly interest in the field gave promise of greater things to come, soon. A generation later, however, we must admit that the progress has been slower than we wished or expected. The "Current Bibliography of Canadian Church History" published each year in the Association's Report doubled in size between 1964 and 1973 and tripled between 1964 and 1978. Since 1978, however, the size has shrunk back to that of 1975, indicating a very real decline in the publication of Canadian religious history. Economic recession has certainly taken its toll in the most recent years, but perhaps we as historians deluded ourselves with the belief that the high level of interest would be sustained and that results would appear quickly. Of all people, historians should have known how slow, how irregular and how unpredictable is progress, if progress really exists.

Turning back to that second phase of the development of Canadian religious history, the interwar years, undoubtedly one of the most important events was the founding of this Association. For any Canadian nationalist there is perhaps a touch of irony in the fact that Dr. Kenney's inspiration and the occasion for his organizational meeting was the visit of the American Historical Association and the American Catholic Historical Association to Toronto at Christmas, 1932. Nevertheless those forty-odd persons whom Dr. Kenney entertained for dinner at his own expense created what was in that day the only Canadian organization devoted to the study of church history and emphasizing Canadian Catholic history. The executive of this new and burgeoning Association (it reached a membership of $\mathbf{3 0 0}$ in only two years) resolved after the first study session in 1933 to publish the papers read there, thus initiating in the depths of the Great Depression a publication programme that continued uninterrupted and was the only undertaking of that type until the appearance of the Anglican Journal of the Canadian Church Historical Society a quarter-century later. 
From the earliest volumes the Study Sessions showed certain patterns of historical interest. Biographical papers consistently filled a considerable proportion of each volume until the mid-1950s, and Canadian topics were in the vast majority in every volume until the mid-1960s when non-Canadian subjects outnumbered Canadian for four consecutive years - an unusual development in view of the great historical interest in Canada aroused by the centenary of Confederation. Single-topic volumes of the Study Sessions have been the exception - in the early years there were two annual meetings apparently devoted exclusively to missions and education, but the format at all other times reflected a catholic rather than a localized or nationalistic approach to history.

Over the past half-century the major vehicle for disseminating Catholic history has been the annual "Study Sessions" volumes of this Association. Those volumes seem about equal quantitatively to major monographs published in the field of English-speaking Canadian Catholic history. Publication of the "Study Sessions" has been, I suggest, the major contribution of the Association, more important than these annual meetings because the printed volumes reach an audience immeasurably bigger than any audience at meetings, and because the volumes provide a permanence for research completed. Equally as important as the Study Session volumes was the introduction in 1964 of the "Current Bibliography of Canadian Church History" as a regular feature of the volumes. Here for the first time students of Canadian history had available an extensive and thorough listing of publications - both monograph and periodical - in the field, and I personally would rank this contribution by the Association as second only to the founding of the Association itself.

A promising but apparently short-lived, development for the CCHA was the publication of a news sheet called "The Bulletin". No. 1 appeared about 1948 and seems to have been the work of Brother Alfred Dooner. Noting that some seventy per cent of the Association's one thousand members were English-speaking, Brother Alfred commented that the Association, now fifteen years old, "supplied a long-felt want especially in our English-speaking provinces." In his opinion, however, the work that lay ahead was still vast for "the Catholic Irish, English and Scotch pioneers ... have been almost entirely forgotten." 3 "Who shall write our history? It is for us Catholics to write our own history. We cannot expect our Protestant fellow Canadians

\footnotetext{
${ }^{3}$ Loc. cit., pp. 1-2.
} 
to write it for us, but up to the present that has seemed to be our attitude." Since these remarks by Brother Alfred thirty-five years ago progress has been made in writing Catholic historical monographs. Biographies, regional, diocesan and congregational histories, have been published; but not in such quantity as might have reassured Doctor Kenney that the vastness of the work was being significantly reduced.

Three decades after the founding of the Association and the appearance of the Siudy Sessions, Michael Sheehan offered his appraisai of the Association and its achievements entitled "Considerations on the ends of the Canadian Catholic Historical Association." ${ }^{4}$ Professor Sheehan listed among the major developments the increasing number of "trained historians" offering papers at the meetings, the decision of the Association to join the meetings of the Learned Societies (an evidence of "a considerable degree of maturity" as was the decision in 1962 to have a joint session with the Canadian Society of Church History.) Professor Sheehan noted particularly the Association's broadening historical interests as reflected in the type of programming for the annual meetings - "a corrective", he commented, "to local interest that... has occasionally run the risk of the antiquarianism that plagued so much ecclesiastical history in the nineteenth century." 5 In closing Professor Sheehan pointed to the crying need for Canadian bibliographic studies (a need that he himself proceeded to remedy the following year with his "Current Bibliography"), and to the need for attention to multiculturalism as a vital feature of Canadian Catholic history.

Today, a score of years after Michael Sheehan's analysis, I would like to offer my impressions of the present and future state of the field of Canadian religious history, non-Catholic as well as Catholic. The keys to my hopes are the words "openness" and "involvement". By openness I mean first a willingness to broaden our perspectives both as to methodology and content. We must be prepared to listen and learn from our cognate and sister disciplines in the humanities and the sciences - to find out what the sociologist, the folklorist, the geographer, the ethnologist, and others can teach us that will expand our understanding of the past.

This kind of openness will in turn demand an openness about the themes we are prepared to examine. We have begun to move out

${ }^{4}$ CCHA, Study Sessions 1963, pp. 23-33.

${ }^{5}$ Ibid., p. 38. 
from (but not to ignore) institutional history. It is time to look again at such topics as missions and to consider the innovative approaches being taken not only by other disciplines but by our fellow francophone historians in Canada. They seem to be blazing new trails in examining popular religion, the role of music and art, devotional practices, moral or ethical issues etc. - all within a Canadian context.

Finally, openness must include accessibility to records on a scale not previously practised. Without historical records there will be no historical research, so the churches must make that leap of faith and trust the good sense of researchers. To close records arbitrarily is to invite the question, what are they hiding? The churches fear that the researcher may be unsympathetic to their particular positions (and in a minority of cases they are probably right), but in fact they are doing no more than denying their own creatureliness. Mistakes will be made by historians, but the road to truth is surely paved with mistakes and with their rectifications.

As for "involvement", perhaps it would be more accurate for my purposes to speak of "interinvolvement" - interinvolvement of disciplines, of traditions, and of resources. There are, for instance, too few parish histories, and even fewer outstanding parish histories. Yet parish history, so often disdained by the self-styled professional historian, is the bed rock on which all more general history is constructed. Better microhistory will make better macrohistory, and the "professionals" should actively seek involvement in local societies - call it a mission if you will - and historical societies should seriously consider offering workshops on aspects of local and congregational history, workshops that would deal not just with writing history but with the collection, preservation and evaluation of those records that are the raw materials for future history.

"Involvement" must mean the marshalling and sharing of resources. Persons with a knowledge of research and writing techniques, or of archival principles or of museum practices, must share their expertise. We seem to have convinced ourselves that the mere application of a generous government grant of money can solve all problems, and perhaps it does, but many worthwhile projects are as much in need of expert aid and moral support as they are of financial largesse. Finally in this regard recent trends in government policy towards support of the humanities strongly suggests that we should be explaining our purposes and our projects to persons and corporations in the private 
sector who might be willing to support research and publication for its own sake, without attaching conditions that can turn history into propaganda.

Yet when all is said, we return to the question of why religious history in Canada is so slow in coming of age. Here I would cite Michael Sheehan's article again. Twenty years ago he pointed to two major problems in the field, the first structural, the second ideological. The structural problem of dealing with the crosscurrents of ethnic diversity is on its way to being solved, thanks more to Canadian sociologists than to Canadian historians. But the ideological problem remains, viz. what is the purpose of studying religious history? Tradi-tionally that purpose has been to edify the faithful and shore up the institution in the face of its enemies, be they denominational, secular or demonic. Hence the preoccupation of the churches with "safe" history. Was it that preoccupation that has slowed the study of Canadian religious history? Has the time come for "daring" history - history that is innovative but honest and human in its errancy? If historians are, as they claim, in search of elusive truth, it is because of the promise that the truth shall make you free. 